\title{
Antioxidant activity of yellow sweet potato (Ipomoea batatas (L.) Lam) after dehydration
}

\author{
Lucia Maria JAEGER DE CARVALHO ${ }^{*}$ (D), Claudia DE LUCAS BAGANHA, José Luiz VIANA DE CARVALHO²
}

\begin{abstract}
Sweet potato (Ipomoea batatas (L.) Lam.) is a plant with great importance in food security, especially in developing countries. Grown in more than 100 countries, it is nutritious and contains high levels of dietary fiber, minerals such as iron and vitamins A, B and C. The aim of this study was to evaluate the antioxidant activity of two cultivars of yellow sweet potatoes Beauregard (biofortified) and Carrot (organic). The ORAC, ABTS and DPPH assays were used to determine the antioxidant activity of raw, bleached and dried sweet potatoes at 40,50 and $60^{\circ} \mathrm{C}$. The results showed that ORAC assay revealed the highest values for antioxidant activity in all conditions of Beauregard and cv. Carrot were tested. Both cultvars can be be use to elaborate functional products as supplements among others. contributing to the consumption of pro-vitamin A rich foods.
\end{abstract}

Keywords: Ipomoea batatas (L.); yellow sweet potatoes; antioxidant activity; ABTS; DPPH; ORAC.

Practical Application: The yellow sweet potato, cv. Beauregard can be reccomended for cultivation by its high beta-carotene contents as well iro and zinc in many different forms of preparation with high nutritious values. In the dried form, can be consumed by low income populations, especially children and scholars, as chips with high beta-carotene and iron and zinc contents.

\section{Introduction}

Sweet potato (Ipomoea batatas (L.) Lam.) is a plant with great importance in food security, especially in developing countries. Grown in more than 100 countries, it is nutritious and contains high levels of dietary fiber, minerals such as iron and vitamins $\mathrm{A}, \mathrm{B}$ and $\mathrm{C}$. Its fresh roots and leaves can be consumed in human and animal food. It is an industrial raw material in the production of flours, sweets, natural pigments (yellow sweet potatoes and others), animal feed and a variety of starch-based products (Zhang et al., 2016) and ranks the fourth place among the most cultivated vegetables in Brazil. Its rusticity, great capacity for climatic adaptation and high energy production per unit of time give an economic and social importance. However, its productivity average in Brazil, is well below of the crop potential. To promote the improvement of this condition, in addition to the adequacy of production technology, it is necessary to adopt more productive cultivars (Silva et al., 2015) as yellow, yellow, purple sweet cultivars as well as biofortified cultivars with have high antioxidant capacity as well good souces of $\beta$-carotene and other bioactive compounds (Murphy et al., 1975).

The biofortified yellow fleshed sweet potato (Ipomoeae batatas), cv. Beauregard (Empresa Brasileira de Pesquisa Agropecuária, 2010) for having high levels of $\beta$-carotene (representing 25 to $30 \%$ of the total carotenoid content) is considered a food with high antioxidant activity and pro-vitamin A activity, with ease cultivation needing low production investment. The way the cultivation of yellow fleshed sweet potatoes and other colored (organic or conventional), genotype, climate, environment, time of harvest and part collected, are important parameters in terms of nutritionally contents of important compounds in a vegetable (Johansson et al., 2014), showing itself to be an excellent choice as a raw material for development of new products and preparations that meet the growing market demand for healthy and nutritious food, practical for consumption and low cost. The $\beta$-carotene is the most active and most bioconversible carotenoid in the human body, comprising 15 to $30 \%$ of all serum carotenoids (Gomes, 2007; Della Lucia et al., 2008).

The pro-vitamin A activity is present in less than $10 \%$ of the identified carotenoids, however most of them have antioxidant capacity, with sequestering action proportional to the number of conjugated double bonds, capable of inactivating singlet oxygen and free radicals (Mercadante \& Rodrigues-Amaya, 2001; Shami \& Moreira, 2004; Ambrósio et al., 2006; Pelissari et al., 2008; Zaccari et al., 2012).

Vegetables contain varied functional compounds. The presence of antioxidants gives them curative and preventive properties of diseases, since the toxic forms of oxygen, derived from human metabolism or the environment, act in the clogging of arteries, are cancerous, cause damage to the joints and the nervous system and participate in the process of aging. For example, if consumed more than once a week, vegetables rich in $\beta$-carotene significantly decrease the risk of lung cancer, 
compared to the risk of individuals who do not consume vegetables (Carvalho et al., 2006).

Functional foods are described as those that benefit, at least, one organic function in addition to basic nutrition, promoting improvements in health and well-being and / or reducing the risk of disease. They should be consumed as food and not as supplements and be effective if consumed in normal amounts from a standard diet.

The antioxidant activity, therefore, must be evaluated in the biofortified yellow and others cultivars of sweet potatoes in view of its high of $\beta$-carotene content, which can implement the elaboration of new products, such as flours, cakes, among other products contributing to the consumption of pro-vitamin A rich foods.

\section{Materials and methods}

\subsection{Raw materials}

The biofortified yellow sweet potato, cultivar Beauregard were cultivated at Embrapa Hortaliças (CNPH), Brasília (DF) and sent to the Food Technology and Instrumental Analysis Laboratory, Federal University of Rio de Janeiro and to Embrapa Food Technology, Rio de Janeiro, for experiments and analysis (Figure 1).

The samples of organic yellow sweet potato, cultivar Carrot were acquired at the organic products (certified) market held weekly at the Health Sciences Center of the Federal University of Rio de Janeiro (Figure 2).

The whole yellow sweet potatoes pulp, Beauregard and the organic Carrot cultivar, in the quantities of $20 \mathrm{~kg}$ and $3 \mathrm{~kg}$, respectively, were washed in chlorinated water at $200 \mathrm{ppm}$ for surface cleaning, rinsed with filtered water and dried with paper towels. The experiments were carried out in triplicate.

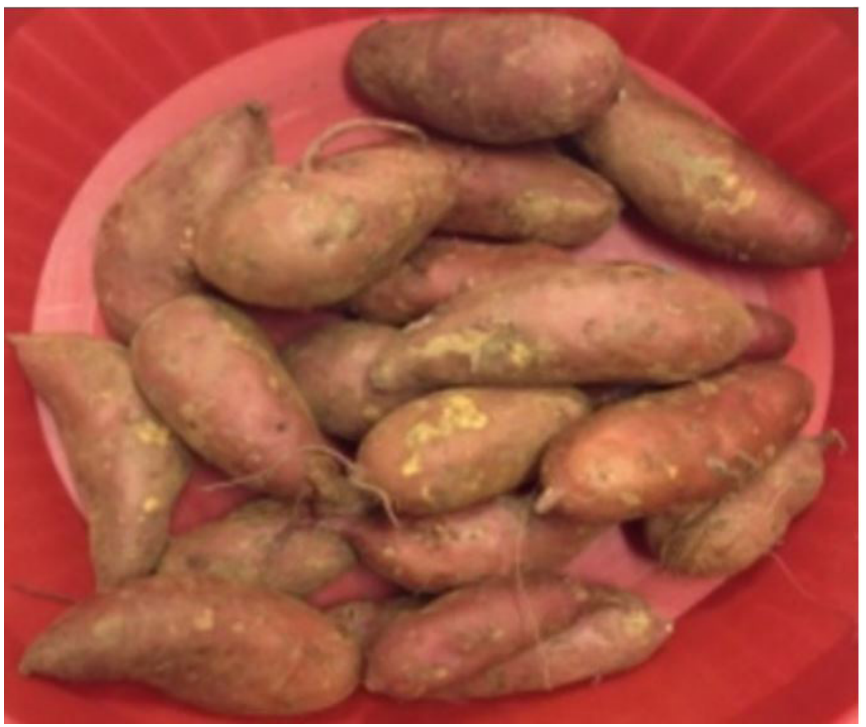

Figure 1. Yellow sweet potato Beauregard with peel (personal archive photo).

\subsection{Preparation of the samples of yellow sweet potato pulp}

Hygiene, peeling and slicing.

The raw yellow sweet potatoes samples were manually peeled with a vegetable peeler and sliced in an electric slicer (Skymsen, model PA-7LE-N) was used with a thickness adjusted to $1 \mathrm{~mm}$ (Figure 3).

\section{Bleaching and molding}

The bleaching was performed by immersion in water at $80^{\circ} \mathrm{C}$ for $4 \mathrm{~min}$, according to Arévalo-Pinedo \& Murr (2005). The process was interrupted by immediately immersing the slices in ice-cold water and removing them immediately. The bleached slices were cut, one by one, with the aid of a square aluminum mold, in the dimensions of $5.5 \times 5.5 \mathrm{~cm}$.

\section{Drying}

The bleached samples were distributed into 64 slices, with a distance of $1 \mathrm{~cm}$ from each other, in a $52 \times 58 \mathrm{~cm}$ grid previously cleaned with $70 \%$ ethanol. The samples were placed

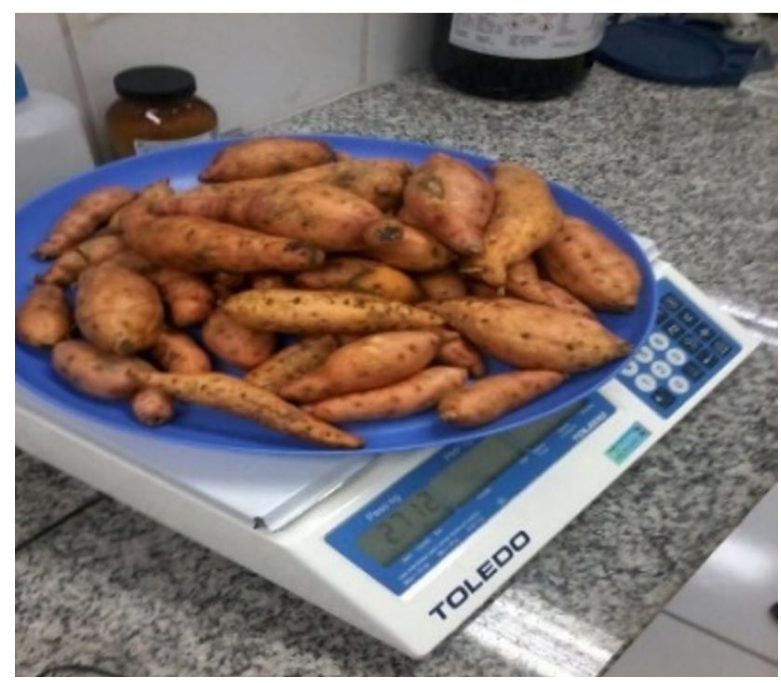

Figure 2. Yellow sweet potato, cv. Carrot with peel (personal archive photo).

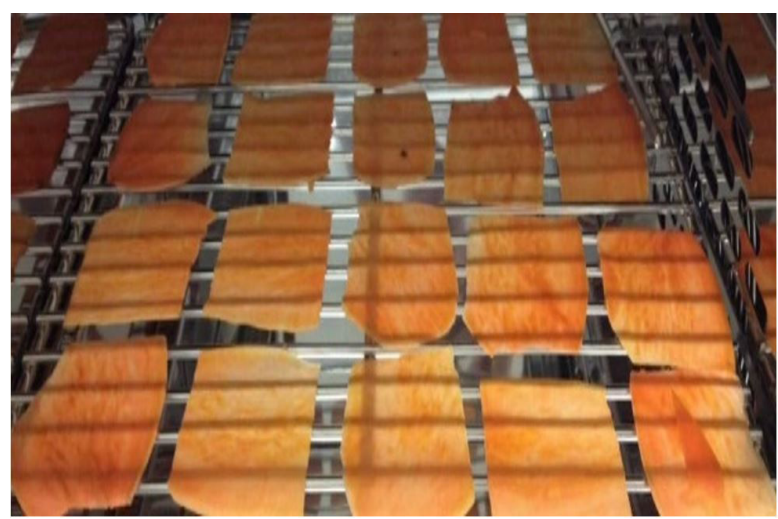

Figure 3. Sliced raw Beauregard sweet potato (personal archive photo). 
in a medium position in a greenhouse with air circulation (Nova Ética, model 400-6 ND), internal dimensions 54 x 59 x $69 \mathrm{~cm}$. The drying processes at $40^{\circ} \mathrm{C}, 50^{\circ} \mathrm{C}$ and $60^{\circ} \mathrm{C}$ were carried out, separately, until the moisture content reached between 6 to $8 \%$, according to Hagenimana et al. (1998).

The raw, bleached (Figure 4) and dried (Figure 5) samples were vacuum-packed, in high density polyethylene bags and kept in a freezer (Metalfrio brand) at $-15^{\circ} \mathrm{C}$, until the analysis. For the experiments, the samples were grounded with a domestic blender (Arno, model LN31).

\subsection{Antioxidant activity}

For samples analysis of antioxidant activity by ABTS, DPPH and ORAC assays, all samples were previously dehydrated in a Liotop freeze dryer - model L101.

\section{ABTS [2,2'-azinobis (3-ethylbenzothiazoline-6-sulfonic acid)}

The methodology adapted from Rufino et al. (2007b) was used. For extraction, approximately $1.25 \mathrm{~g}$ of lyophilized sample were weighed in a beaker and $10 \mathrm{ml}$ of $70 \%$ acetone were added.

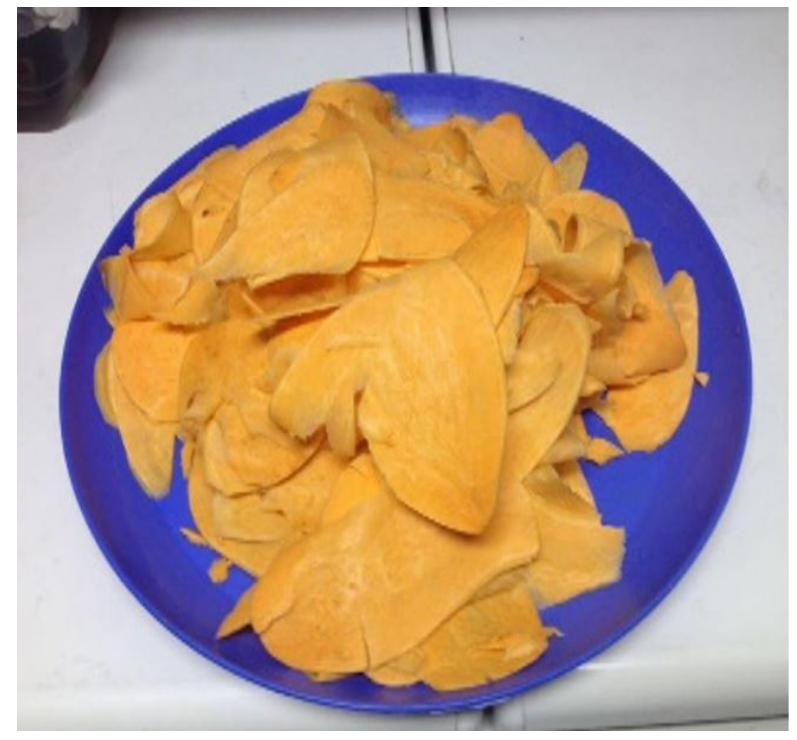

Figure 4. Bleanched Beauregard sweet potato, before the drying process (personal archive photo).

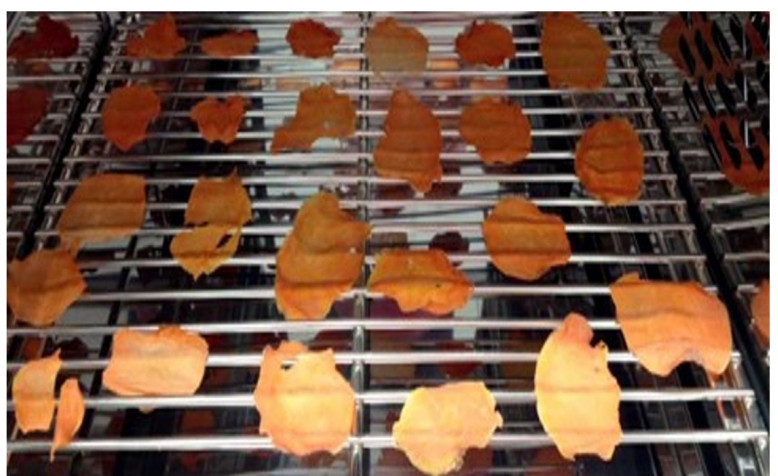

Figure 5. Dried Beauregard sweet potato (personal archive photo).
The beaker, protected from light with aluminum foil, was left under magnetic stirring for $60 \mathrm{~min}$. At the end, were filtered, transferred to a $25 \mathrm{~mL}$ volumetric flask and swollen with distilled water. This extract was used for both ABTS and DPPH analysis.

Briefly, to prepare the ABTS $\cdot{ }^{+}$radical, $5 \mathrm{~mL}$ of $7 \mathrm{mM}$ ABTS solution and $88 \mu \mathrm{L}$ of $140 \mathrm{mM}$ potassium persulfate solution were used. This reaction mixture was kept in the dark for $16 \mathrm{~h}$ at room temperature. Then, a $1 \mathrm{~mL}$ aliquot was removed from this mixture, which was gradually diluted with ethanol, until it showed an absorbance between 0.65 and $0.75 \mathrm{~nm}$., and the reading was performed at $734 \mathrm{~nm}$, in a spectrophotometer (Shimadzu, model UV-2700). Ethanol was used to calibrate the device.

For the determination of the Trolox standard curve, from its standard solution $2.000 \mu \mathrm{M}$, the test tubes were prepared.

The blank was read with $2.5 \mathrm{~mL}$ of ABTS + diluted in $500 \mu \mathrm{L}$ of ethanol. After adding the reagents, the tubes remained for $6 \mathrm{~min}$ protected from light and, immediately, read at $734 \mathrm{~nm}$. All readings were done in triplicate.

To obtain the graph of the standard curve, the Trolox concentrations, in $\mu \mathrm{M}$, were placed on the abscissa axis and the corresponding absorbances on the ordinate one. The equation of the obtained the line was calculated. The calculation absorbance for 1,000 $\mu \mathrm{M}$ of Trolox according with Equation 1 .

$y=-a x+b$

Where, $\mathrm{x}=1,000 \mu \mathrm{M}$ of Trolox; $\mathrm{y}=$ absorbance equivalent to $1,000 \mu \mathrm{M}$ of Trolox

$$
\begin{gathered}
1,000 \mu M \text { Trolox }= \\
\text { Antioxidant activity }\left(\mu M \text { Trolox } \cdot g^{-1}\right) \\
(\text { extract dilution }: 1000)
\end{gathered}
$$

\section{DPPH (2,2-diphenyl-1-picryl-hydrazil) assay}

The methodology of Rufino et al. (2007a) was used, with adaptations. The same extracts prepared for ABTS analyzes were used. To prepare the DPPH solution, $7 \mathrm{mg}$ of it were solubilized in methanol and swelled in a $250 \mathrm{~mL}$ volumetric flask. To determine the standard Trolox curve, from its standard solution 2,000 $\mu \mathrm{M}$, in methanol, the test tubes were prepared. The absorbances were read in the test tubes as as well the blanks. After adding the reagents, the tubes remained for $30 \mathrm{~min}$ protected by light and, immediately, and read at $515 \mathrm{\eta m}$. Methanol was used to calibrate the equipment. All readings were done in triplicate.

To obtain the graphic from the standard curve, the Trolox concentrations, in $\mu \mathrm{M}$, were placed on the abscissa axis and the corresponding absorbances on the ordinate axis. The equation of the obtained line was calculated. With this equation, the absobance for 1,000 $\mu \mathrm{M}$ of Trolox, according with Equation 2.

$y=-a x+b$

Where:

$\mathrm{x}=1,000 \mu \mathrm{M}$ of Trolox; $\mathrm{y}=$ absorbance equivalent to $1.000 \mu \mathrm{M}$ of Trolox. 
To calculate the antioxidant activity of the extracts, dilutions, in $\mathrm{mg} . \mathrm{L}^{-1}$, were placed on the abscissa axis; the corresponding absorbances, subtracting the whites from the ordinate axis. The equation of the obtained line was calculated. The value of $y$ in the equation was replaced by the absorbance value equivalent to $1.000 \mu \mathrm{M}$ of Trolox (Equation 3):

$$
x: y=-a x+b
$$

Where; $\mathrm{x}=$ dilution of the extract, in $\mathrm{mg} . \mathrm{L}^{-1}$, equivalent to 1,000 $\mu \mathrm{M}$ of Trolox; $\mathrm{y}=$ absorbance equivalent to $1,000 \mu \mathrm{M}$ of Trolox

$$
\begin{gathered}
1,000 \mu M \text { Trolox }= \\
\text { Antioxidant Activity }\left(\mu M \text { Trolox. } g^{-1}\right) \\
(\text { extract dilution }: 1000)
\end{gathered}
$$

\section{Oxygen Radical Absorbance Capacity (ORAC)}

The ORAC was carried out according with the methodology of Prior \& Cao (1999). For sample preparation, approximately $0.01 \mathrm{~g}$ of the lyophilized sample was weighed and solubilized with $1 \mathrm{~mL}$ of dimethyl sulfoxide (DMSO). Then, transferred to a $10 \mathrm{~mL}$ volumetric flask and swollen with phosphate buffer solution $\mathrm{pH}$ 7.4. The Trolox solution was prepared by weighing $0.0125 \mathrm{~g}$ of Trolox and solubilized in buffer the solution, transferred to a $50 \mathrm{~mL}$ volumetric flask and the volume was completed. A $1 \mathrm{~mL}$ aliquot of this solution was transferred to a $10 \mathrm{~mL}$ volumetric flask and swollen. Dilution of $116.66 \mu \mathrm{M}$ of disodium fluorescein solution was performed, transferring a $25 \mu \mathrm{L}$ aliquot to a $25 \mathrm{~mL}$ volumetric flask and swelling with buffer solution, $0.10848 \mathrm{~g}$ of AAPH was dissolved with buffer solution, and the volume completed in a $10 \mathrm{ml}$ volumetric flask. The preparation of the dilutions for the calibration curve was done.

In preparing the plates for the readings, the added volumes were: Control: $80 \mu \mathrm{L}$ of buffer and $120 \mu \mathrm{L}$ of fluorescein; Blank: $20 \mu \mathrm{L}$ of buffer and $120 \mu \mathrm{L}$ of fluorescein and $60 \mu \mathrm{L}$ of AAPH; Trolox: $20 \mu \mathrm{L}$ of each Trolox concentration. $120 \mu \mathrm{L}$ of fluorescein and $60 \mu \mathrm{L}$ of AAPH; Sample: $20 \mu \mathrm{L}$ of each sample concentration. $120 \mu \mathrm{L}$ of fluorescein and $60 \mu \mathrm{L}$ of AAPH (Equation 4).

$$
\% A A=\frac{\text { mass of the sample }}{\text { mass of Trolox }} \times 100
$$

\subsection{Experiments design and statistical analysis}

All experiments were carried out in 3 repetitions for each sample. The results were evaluated using Analysis of Variance (ANOVA). in a completely randomized design. to assess the presence of significant effect $(P \leq 0.05)$. The Tukey test was used to determine the differences between the averages obtained.

\section{Results and discussion}

\subsection{Antioxidant activity by ABTS assay}

The standard Trolox curve for the ABTS assay presented a determination coefficient of $\mathrm{R}^{2}=0.9999$, quite high.
The antioxidant activity by the ABTS assay of organic sweet potato, cv. Carrot are presented on Table 1.

There were significative differences $(P \leq 0.05)$ among samples of Beauregard sweet potatoes varying from 23.02 (raw), 19.71 (bleached), 7.01 and 7,89 (dried at 40 and $50^{\circ} \mathrm{C}$ ) and 5.48 (dried at $60^{\circ} \mathrm{C}$ ) as well as in the organic, cv. Carrot samples after processes. However, the values were quite slow compared with Beauregard (Table 1).

Comparing the three drying processes still have no statistical differences $(P \leq 0.05)$ between the antioxidant activity after drying at 40 and $50{ }^{\circ} \mathrm{C}$. The same behavior was observed in the organic, cv. Carrot. Raw Beauregard presented higher antioxidant activity than cv. Carrot (47.57\%).

It was observed a reduction of $94.95 \%$ in the antioxidant activity in dried Beauregard slices $\left(40^{\circ} \mathrm{C}\right.$ for $\left.5 \mathrm{~h}\right) ; 94.29 \%\left(50{ }^{\circ} \mathrm{C}\right.$ after $2 \mathrm{~h}$ ), and $87.62 \%\left(60{ }^{\circ} \mathrm{C}\right.$ for $\left.1 \mathrm{~h}\right)$.

After drying at $60^{\circ} \mathrm{C}$, the Beauregard showed $67.73 \%$ higher antioxidant activity than the cv. Carrot.

As a result of the drying processes with cv. Carrot compared to blanched slices (wet basis) no statistical differences in the antioxidant activity, only the samples dried at $60{ }^{\circ} \mathrm{C}$.

Vasco et al. (2008) used the ABTS assay in plum (Prunus domestica L.), strawberry, passion fruit (Passiflora edulis Sims), guava (Psidium guajava L.) and mango (Mangifera indica L.). The raw Beauregard sweet potato presented, antioxidant activity higher than strawberry $(20 \mu \mathrm{mol})$, mango $(5 \mu \mathrm{mol})$, plum (35 $\mu \mathrm{mol})$, and guava $\left(40 \mu \mathrm{mol}\right.$ of Trolox. $\left.\mathrm{g}^{-1}\right)$ but compared with the passion fruit $\left(110 \mu \mathrm{mol}\right.$ of Trolox. $\left.\mathrm{g}^{-1}\right)$ antioxidant activity was higher. On the other hand, the raw organic sweet potato, cv. Carrot, stood out only of the mango.

Dried Beauregard slices compared to bleached ones showed no statistical difference in antioxidant activity drying at $60^{\circ} \mathrm{C}$.

Comparing the three drying processes of cv. Carrot there was no statistical differences between the antioxidant activity, after drying at 40 and $50{ }^{\circ} \mathrm{C}$, respectively.

Table 1. Antioxidant actvity by ABTS assay of Beauregard and cv. Carrot yellow sweet potatoes.

\begin{tabular}{lr}
\hline \multicolumn{1}{c}{ Antioxidant Actvity $\left(\mu\right.$ mol de Trolox.g $\left.{ }^{-1}\right)$ Wet basis } \\
\hline Beauregard & $23.02 \pm 2.50^{\mathrm{a}}$ \\
Raw & $19.71 \pm 1.23^{\mathrm{b}}$ \\
Bleaching & $7.01 \pm 0.02^{\mathrm{c}}$ \\
Dried at $40^{\circ} \mathrm{C}$ & $7.89 \pm 0.04^{\mathrm{c}}$ \\
Dried at $50^{\circ} \mathrm{C}$ & $16.98 \pm 1.50^{\mathrm{b}}$ \\
Dried at $60^{\circ} \mathrm{C}$ & \\
Organic Carrot & $12.07 \pm 1.70^{\mathrm{a}}$ \\
Raw & $5.17 \pm 0.09^{\mathrm{b}}$ \\
Bleaching & $8.46 \pm 0.01^{\mathrm{c}}$ \\
Dryed at $40^{\circ} \mathrm{C}$ & $7.45 \pm 0.04^{\mathrm{c}}$ \\
Dryed at $50^{\circ} \mathrm{C}$ & $5.48 \pm 0.02^{\mathrm{b}}$ \\
Dryed at $60^{\circ} \mathrm{C}$ & Columns with same letters did not difer statiscally significantly at $\mathrm{P} \leq 0.05$.
\end{tabular}


After drying at $40{ }^{\circ} \mathrm{C}, \mathrm{cv}$. Carrot showed $20.68 \%$ higher antioxidant activity than Beauregard.

Beauregard sweet potato presented the shortest time of exposure to heat and despite the higher temperature applied, best preserved the antioxidant activity.

\subsection{Antioxidant activity by DPPH assay}

The standard Trolox curve for the DPPH test can be observed, which showed a coefficient of determination (R2) of 0.9992 , considered high.

The antioxidant activity by DPPH assay of Beauregard and, the organic, cv. Carrot sweet potatoes can be observed on Table 2.

After bleaching, the Beauregard sweet potato presented a statistical difference in antioxidant activity (72.05\%) higher than cv. Carrot.

The Beauregard drying processes compared to bleached slices presented significative differences $(P \leq 0.05)$ in antioxidant activity after the three drying processes as well as, cv. Carrot. Exception was observed in Beauregard samples dried at 50 and $60{ }^{\circ} \mathrm{C}$ (no significative differences).

The Beauregard dried at $60^{\circ} \mathrm{C}$ presented higher antioxidant activity (87.91\%) than the cv. Carrot.

Beauregard had the shortest time of exposure to heat despite the higher temperature, was that the best preserved the antioxidant activity.

Thaipong et al. (2006) evaluated the antioxidant activity of four raw guava cultivars by DPPH assay found values between 16.2 and $32.0 \mu \mathrm{mol}$ of Trolox.g ${ }^{-1}$. Raw Beauregard and cv. Carrot sweet potatoes showed highest antioxidant activity values than them.

Fidrianny et al. (2018) evaluated the antioxidant activity (DPPH) and phytochemical content of four varieties of sweet potato extracts in order to explore the correlation from them. They observed that DPPH assay showed that all different ethyl acetate and ethanolic extracts of four varieties of sweet potato

Table 2. Antioxidant activity by DPPH assay of Beauregard and Carrot yellow sweet potatoes.

\begin{tabular}{lc}
\hline \multicolumn{1}{c}{ Antioxidant Activity $\left(\mu \mathrm{mol}\right.$ of Trolox.g $\left.{ }^{-1}\right)$ Wet Basis } \\
\hline Beauregard & $12.44 \pm 0.13^{\mathrm{a}}$ \\
Raw & $18.96 \pm 0.23^{\mathrm{b}}$ \\
Bleaching & $4.49 \pm 1.45^{\mathrm{c}}$ \\
Dryed at $40^{\circ} \mathrm{C}$ & $10.20 \pm 4.75^{\mathrm{a}}$ \\
Dryed at $50^{\circ} \mathrm{C}$ & $13.81 \pm 0.38^{\mathrm{a}}$ \\
Dryed at $60^{\circ} \mathrm{C}$ & \\
Organic, $\mathrm{cv} . \mathrm{Carrot}$ & $4.97 \pm 0.34^{\mathrm{a}}$ \\
Raw & $5.30 \pm 0.09^{\mathrm{a}, \mathrm{b}}$ \\
Bleaching & $5.73 \pm 0.45^{\mathrm{b}}$ \\
Dried at $40^{\circ} \mathrm{C}$ & $3.41 \pm 0.43^{\mathrm{c}}$ \\
Dried at $50^{\circ} \mathrm{C}$ & $1.67 \pm 0.35^{\mathrm{d}}$ \\
Dried at $60^{\circ} \mathrm{C}$ & \\
\hline Columns with same letters did not difer statiscally significantly at $\mathrm{P} \leq 0.05$.
\end{tabular}

are classified as strong and with very strong antioxidant activity as well Yang et al. (2010).

Šlosár et al. (2020) tested the effect of the cultivar on the important qualitative and quantitative (yield of marketable tubers per plant, average weight of marketable tubers, yield of marketable tubers per hectare, share of marketable tubers) and qualitative (DPPH and polyphenol content) parameters of sweet potatoes grown in Slovak Republic. The highest marketable tubers ratio was found in yellow cultivar Beauregard' $(87.17 \%)$ and the highest antioxidant activity (61.07\%) and polyphenol content (4506.90 mg. $\mathrm{Kg}^{-1}$ ) were found just in purple cultivar Višnjica purple. The study revealed that sweet potato is expressed by good yield potential, together with its quality, in conditions of Slovak Republic, or Middle Europe, in generally.

Thaipong et al. (2006) determined the antioxidant activity of four raw guava cultivars by DPPH assay finding values between 16.2 and $32.0 \mu \mathrm{mol}$ of Trolox. $\mathrm{g}^{-1}$. Raw Beauregard and cv. Carrot showed lower antioxidant activity.

\subsection{Antioxidant activity by ORAC assay}

The antioxidant activity values measured by the ORAC assay of Beauregard and $c v$. Carrot samples are showed on Table 3.

After the bleaching, Beauregard revealed no statistical difference $(P \leq 0.05)$ in antioxidant activity compared to raw sample. However, observing the cv. Carrot samples significative differences were found.

After bleaching Beauregard presented antioxidant activity (77.07\%) higher than cv. Carrot.

After drying at $60{ }^{\circ} \mathrm{C}$, Beauregard showed $41.32 \%$ higher antioxidant activity than the cv. Carrot.

For both sweet potato cultivars, the shortest time of exposure to heat, despite the higher temperature, was that the best preserved the antioxidant activity.

Comparing the three drying processes for Beauregard, there was no statistical difference in the antioxidant activity by

Table 3. Activity antioxidant by ORAC assay of Beauregard and cv. Carrot yellow sweet potatoes.

\begin{tabular}{lc}
\hline \multicolumn{1}{c}{ Antioxidant Activity $\left(\mu \mathrm{mol}\right.$ of Trolox. $\left.\mathrm{g}^{-1}\right)$ Wet basis } \\
\hline Beauregard & $53.28 \pm 2.12^{\mathrm{a}}$ \\
Raw & $51.68 \pm 0.06^{\mathrm{a}}$ \\
Bleaching & $28.09 \pm 4.97^{\mathrm{b} .}$ \\
Dried at $40^{\circ} \mathrm{C}$ & $29.26 \pm 7.48^{\mathrm{b} . \mathrm{c}}$ \\
Dried at $50^{\circ} \mathrm{C}$ & $37.56 \pm 6.90^{\mathrm{c}}$ \\
Dried at $60^{\circ} \mathrm{C}$ & \\
Organic, cv. Carrot & $20.07 \pm 4.76^{\mathrm{a}}$ \\
Raw & $11.85 \pm 2.21^{\mathrm{b}}$ \\
Bleaching & $5.17 \pm 1.99^{\mathrm{b}}$ \\
Dried at $40^{\circ} \mathrm{C}$ & $17.71 \pm 0.85^{\mathrm{a} \cdot \mathrm{b}}$ \\
Dried at $50^{\circ} \mathrm{C}$ & $22.04 \pm 2.86^{\mathrm{a}}$ \\
Dried at $60^{\circ} \mathrm{C}$ & Columns with same letters did not difer statiscally significantly at $\mathrm{P} \leq 0.05$.
\end{tabular}


ORAC assay in drying at 40 and $50{ }^{\circ} \mathrm{C}$ and between drying at 50 and $60^{\circ} \mathrm{C}$.

Teow et al. (2007) evaluated the antioxidant activities by ORAC in 19 raw sweet potato cultivars. They found in white pulp and yellow pulp ( 2.72 to $3.33 \mu \mathrm{mol}$ of Trolox. $\left.\mathrm{g}^{-1}\right)$; in yellow pulp (5.89 to $18.2 \mu \mathrm{mol}$ of trolox. $\mathrm{g}^{-1}$ ); in purple pulp (14.7 to $29.2 \mu \mathrm{mol}$ of trolox. $\left.\mathrm{g}^{-1}\right)$. Beauregard and cv. Carrot sweet potatoes showed antioxidant activities higher values compared to them.

Cabello-Hurtado et al. (2012) reported that glycosinolates (GLSs) are of great interest for their potential as antioxidant and anticancer agents. They used the ABTS, DPPH and ORAC assays evaluating the antioxidant activity of cauliflower GLSs. They observed that ORAC showing great antioxidant activity.

Patel, \& Patel (2020) evaluating the antioxidant activity of different fruits from India (amla; bael fruit; guava white; green grapes; mango; papaya; pomegranate; tamarind pulp and tomato), indicated that majority of the fresh fruits studied were rich in phenolic antioxidants with potent ORAC imply their importance to human health.

Zeghad et al. (2019) evaluated the antioxidant activity of four fruits from Vitis vinifera, Punica granatum, Citrus aurantium and Opuntiaficus indica from Algeria using the ABTS, DPPH and ORAC assays. Among the four fruits tested, Vitis vinifera hydroalcoholic extract showed the highest antioxidant capacity among all methods observing that antioxidant activity and total phenolic content of the plants were significantly different $(P<0.001)$ as used in this study for the three different antioxidant activity assays.

Sun et al. (2019) assessed the phenolic profiles, cellular antioxidant and antiproliferative activities in 10 varieties of sweet potato (Ipomoea Batatas) roots. They observed an extremely significant correlation between phenolic compounds and total antioxidant activity was also revealed by Pearson correlation analysis $(P<0.05)$. However, no significant relevance was found between intracellular antioxidant activity and total phenolic content or flesh colour of sweet potatoes.

Floegel et al. (2011) compared the two most common radical scavenging assays ABTS and DPPH) in the 50 most popular antioxidant-rich fruits, vegetables and beverages in the US diet. There was a strong relationship among both assays. Antioxidant capacity by ABTS was significantly higher for fruits, vegetables and beverages compared to ABTS. The high-pigmented and hydrophilic antioxidants were better reflected by ABTS than $\mathrm{DPPH}$. These data suggest that ABTS assay may be more useful than DPPH for detecting antioxidant capacity in a variety of foods.

Burgos et al. (2013) evaluated the effect of boiling on phenolic concentrations of Andean potatoes (light to deep purple fleshed) as well as the antioxidant activity. Boiled deep purple fleshed potatoes have proved to be a good source of anthocyanins with high antioxidant activity.

Murador et al. (2018) reviewed prior studies that evaluated the effects of cooking methods on polyphenol content and antioxidant activity in vegetables to obtain meta-analysis of the findings using the weighted response ratios $\left(\mathrm{R}^{\star}\right)$, observing that cooking methods as baking $\left(\mathrm{R}^{\star}=0.51\right)$, blanching $\left(\mathrm{R}^{\star}=0.94\right)$, boiling $\left(\mathrm{R}^{\star}=0.62\right)$, microwaving $\left(\mathrm{R}^{\star}=0.54\right)$ and pressure cooking $\left(R^{*}=0.47\right)$ presented significant reductions in polyphenol levels as well as significant decreases in antioxidant activity levels were noted after baking $\left(\mathrm{R}^{\star}=0.45\right)$ and boiling $\left(\mathrm{R}^{\star}=0.76\right)$ while significant increases were observed after frying $\left(\mathrm{R}^{\star}=2.26\right)$ and steaming $\left(\mathrm{R}^{\star}=1.52\right)$.

Hamouz et al. (2011) evaluated the antioxidant activity (AOA) and total anthocyanin contents in flesh potato with different colours grown in the Czech Republic. Four yellow and White: six purple and four red-fleshed varieties grown in 2009 at two different sites. For purple and red fleshed varieties TAC average, it ranged from 61.5 to 573.5 cyanidin mg. $\mathrm{kg}^{-1}$ and a significant effect of the variety of TAC was found. Between purple and red fleshed varieties significant differences in antioxidant activity still were found, both high and low values of AOA showed the same varieties as in the case of the total anthocyanin contents. Among experimental sites, higher AOA was also demonstrated at Přerov and Labem. Correlation analysis showed a strong correlation between AOA and TAC ( $r=0.8099)$.

The dried Beauregard and cv. Carrot can be as a functional raw material option, with antioxidant activity proven in vitro, able to meet $100 \%$ of the RDI $\beta$-carotene (data not reported in this study) for adults with the consumption of about 10 grams daily.

The raw sweet potatoes Beauregard and cv. Carrot showed antioxidant activities higher than mango (Mangifera indica L.) and to other sweet potato cultivars, as reported in the literature.

Beauregard sweet potato obtained the best performance as a raw material with functional properties.

Finally, the high antioxidant activity of the both cultivars studied can be explained by the fact they are rich in $\beta$-carotene.

\section{Conclusions}

Comparing the three drying processes of Beauregard, there was no statistical difference in the antioxidant activity by ORAC assay in drying at 40 and $50{ }^{\circ} \mathrm{C}$ and between drying at 50 and $60{ }^{\circ} \mathrm{C}$, allowing it was the best assay to evaluate the antioxidant activity in yellow Sweet potatoes.

Additionally, Beauregard sweet potato showed the highest iron and zinc values and $\beta$-carotene in the raw samples bleached and dried (data not reported), in relation to cv. Carrot. It was expected since Beauregard yellow sweet potato is a biofortified cultivar.

The cultivar Beauregard should be recommended for cultivation and in the preparation of nutritious foods and as a supplement in the dried form as another consumption option, especially for low-income populations.

\section{Acknowledgements}

The authors would like the thanks BioFORT and Embrapa Hortaliças (CNPH), Brasília (DF) for the biofortified yellow sweet potato, cv. Beauregard, samples, and Embrapa Food Technology, Rio de Janeiro (RJ). 


\section{References}

Ambrósio, C. L. B., Campos, F. A. C. S., \& Faro, Z. P. (2006). Carotenoides como alternativa contra a hipovitaminose A. Revista de Nutrição, 19(2), 233-243. http://dx.doi.org/10.1590/S1415-52732006000200010.

Arévalo-Pinedo, A., \& Murr, F. E. X. (2005). Influence of pressure and temperature and pre-treatments in the carrot and pumpkin vacuum drying. Food Science and Technology, 25(4), 636-643.

Burgos, G., Amoros, W., Muñoa, L., Sosa, P., Cayhualla, E., Sanchez, C., Díaz, C., \& Bonierbale, M. (2013). Total phenolic, total anthocyanin and phenolic acid concentrations and antioxidant activity of purplefleshed potatoes as affected by boiling. Journal of Food Composition and Analysis, 30(1), 6-12. https://doi.org/10.1016/j.jfca.2012.12.001

Burgos, G., Amoros, W., Muñoa, L., Sosa, P., Cayhualla, E., Sanchez, C., Díaz, C., \& Bonierbale, M. (2013). Total phenolic, total anthocyanin and phenolic acid concentrations and antioxidant activity of purplefleshed potatoes as affected by boiling. Journal of Food Composition and Analysis, 30(1), 6-12. https://doi.org/10.1016/j.jfca.2012.12.001.

Cabello-Hurtado, F., Gicquel, M., \& Eesnault, M. A. (2012). Evaluation of the antioxidant potential of cauliflower (Brassica oleracea) from a glucosinolate content perspective. Food Chemistry, 132(2), 10031009. http://dx.doi.org/10.1016/j.foodchem.2011.11.086.

Carvalho, P. G. B., Machado, C. M. M., Moretti, C. L., \& Fonseca, M. E. N. (2006). Hortaliças como alimentos funcionais. Horticultura Brasileira, 24(4), 397-404. http://dx.doi.org/10.1590/S010205362006000400001.

Della Lucia, C. M., Campos, F. M., Mata, G. M. S. C., \& Sant’ana, H. M. P. (2008). Controle de perdas de carotenoides em hortaliças preparadas em unidade de alimentação e nutrição hospitalar. Ciencia \& Saúde Coletiva, 13(5), 1627-1636. http://dx.doi.org/10.1590/ S1413-81232008000500026. PMid:18813663.

Empresa Brasileira de Pesquisa Agropecuária - EMBRAPA. Batata Doce Beauregard: A Batata Vitaminada - Centro Nacional de Pesquisa de Hortaliças. Retrieved from http://ainfo.cnptia.embrapa.br/digital/ bitstream/item/23698/1/batatavitaminada.pdf/http://nutricao.saude. gov.br/evento/5_congresso_frutas_hortalicas/trabalhoAprovado. php?coTrabalho=NTQ5NQ==. /eref $>$

Fidrianny, I., Suhendy, H., \& Insanu, M. (2018). Correlation of phytochemical content with antioxidant potential of various sweet potato (Ipomoea batatas) in West Java, Indonesia. Asian Pacific Journal of Tropical Biomedicine, 8(1), 25-30. http://dx.doi. org/10.4103/2221-1691.221131.

Floegel, A., Kim, D., Chung, S., Koo, S. I., \& Chun, O. K. (2011). Comparison of ABTS/DPPH assays to measure antioxidant capacity in popular antioxidant-rich US foods. Journal of Food Composition and Analysis, 24(7), 1043-1048. http://dx.doi.org/10.1016/j. jfca.2011.01.008.

Gomes, F. D. S. (2007). Carotenoides: uma possível proteção contra o desenvolvimento de câncer. Revista de Nutrição, 20(5), 537-548. http://dx.doi.org/10.1590/S1415-52732007000500009.

Hagenimana, V., Carey, E. E., Gichuki, S. T., Oyunga, M. A., \& Imungi, J. K. (1998). Carotenoid contents in fresh. dried and processed sweetpotato products. Ecology of Food and Nutrition, 37(5), 455-473. http://dx.doi.org/10.1080/03670244.1998.9991560.

Hamouz, K., Lachman, J., Pazderů, K., Tomášek J., Hejtmánková, K., \& Pivec, V. (2011). Differences in anthocyanin content and antioxidant activity of potato tubers with different flesh colour. Plant Soil Environment, 57(10): 478-485.

Johansson, E., Hussain, A., Kuktaite, R., Andersson, S. C., \& Olsson, M. E. (2014). Contribution of organically grown crops to human health. International Journal of Environmental Research and Public
Health, 11(4), 3870-3893. http://dx.doi.org/10.3390/ijerph110403870. PMid:24717360.

Mercadante, A. Z., \& Rodriguez-Amaya, D. (2001). Confirmação da identidade da a- criptoxantina e incidência de carotenoides minoritários provitamínicos a em verduras folhosas verdes. Food Science and Technology, 21(2). http://dx.doi.org/10.1590/S010120612001000200017.

Murador, D., Braga, A. R., Cunha, D., \& Rosso, V. (2018). Alterations in phenolic compound levels and antioxidant activity in response to cooking technique effects: a meta-analytic investigation. Critical Reviews in Food Science and Nutrition, 58(2), 169-177. http://dx.doi. org/10.1080/10408398.2016.1140121

Murphy, E. W., Criner, P. E., \& Gray, B. C. (1975). Comparison of methods for calculating retention of nutrients in cooked foods. Journal of Agricultural and Food Chemistry, 23(6), 1153-1157. http:// dx.doi.org/10.1021/jf60202a021. PMid:1238446.

Patel, H., \& Patel, V. H. (2020). Oxigen Radical Absorbance Capacity (ORAC) and in vitro anti-inflammatory activity of fruits of diferente fruits. Indian Journal of Agricultural Biochemistry, 33(1), 49-55. http://dx.doi.org/10.5958/0974-4479.2020.00008.8.

Pelissari, F. M., Rona, M. S. S., \& Matioli, G. (2008). O licopeno e suas contribuições na prevenção de doenças. Arquivos do MUDI, 12(1), 5-11.

Prior, R. L., \& Cao, G. (1999). In vivo total antioxidant capacity: comparison of different analytical methods. Free Radical Biology \& Medicine, 27(11), 11-12. http://dx.doi.org/10.1016/S0891-5849(99)00203-8. PMid:10641708.

Rufino, M. S. M., Alves, R. E., Brito, E. S., Morais, S. M., Sampaio, C. G., Pérez-Jiménez, J., \& Saura-Calixto, F. D. (2007a). Metodologia científica: determinação da atividade antioxidante total em frutas pela captura do radical livre DPPH - Comunicado Técnico. Fortaleza: Embrapa.

Rufino, M. S. M., Alves, R. E., Brito, E. S., Morais, S. M., Sampaio, C. G., Pérez-Jiménez, J., \& Saura-Calixto, F. D. (2007b). Metodologia científica: determinação da atividade antioxidante total em frutas pela captura do radical livre ABTS.+ - Comunicado Técnico. Fortaleza: Embrapa.

Shami, N. J. I. E., \& Moreira, E. A. M. (2004). Licopeno como agente antioxidante. Revista de Nutrição, 17(2), 227-236. http://dx.doi. org/10.1590/S1415-52732004000200009.

Silva, G. O., Suinaga, F. A., Ponijaleki, R., \& Amaro, G. B. (2015). Desempenho de cultivares de batata-doce para caracteres relacionados com o rendimento de raiz. Revista Ceres, 62(4), 379-383. http:// dx.doi.org/10.1590/0034-737X201562040007.

Šlosár, M., Hegedűsová, A., Hegedűs, O., Mezeyová, I., \& Timoracká, M. (2020). The effect of cultivar on selected quantitative and qualitative parameters of sweet potatoes (Ipomoea batatas L.) grown in Slovak Republic. Journal of Central European Agriculture, 21(2), 344-353. http://dx.doi.org/10.5513/JCEA01/21.2.2684.

Sun, Y., Pan, Z., Yang, C. N., Jia, Z., \& Guo, X. (2019). Comparative assessment of phenolic profiles, cellular antioxidant and antiproliferative activities in ten varieties of sweet potato (Ipomoea Batatas) storage roots. Molecules, 24(24), 4476. http://dx.doi.org/10.3390/ molecules24244476. PMid:31817653.

Teow, C. C., Truong, V., Mcfeeters, R. F., Thompson, R. L., Pecota, K. V., \& Yencho, G. C. (2007). Antioxidant activities. phenolic and $\beta$-carotene contents of sweet potato genotypes with varying flesh colours. Food Chemistry, 103(3), 829-838. http://dx.doi.org/10.1016/j. foodchem.2006.09.033. 
Thaipong, K., Boonprakob, U., Crosby, K., Cisneros-Zevallos, L., \& Byrne, D. H. (2006). Comparison of ABTS. DPPH. FRAP. and ORAC assays for estimating antioxidant activity from guava fruit extracts. Journal of Food Composition and Analysis, 19(6-7), 669-675. http:// dx.doi.org/10.1016/j.jfca.2006.01.003.

Vasco, C., Ruales, J., \& Kamal-Eldin, A. (2008). Total phenolic compounds and antioxidant capacities of major fruits from Ecuador. Food Chemistry, 111(4), 816-823. http://dx.doi.org/10.1016/j.foodchem.2008.04.054.

Yang, J., Chen, J. F., Zhao, Y., \& Mao, L. C. (2010). Effects of drying processes on the antioxidant properties in sweet potatoes. Agricultural Sciences in China, 9(10), 1522-1529. http://dx.doi.org/10.1016/ S1671-2927(09)60246-7.
Zaccari, F., Galietta, G., Soto, B., \& Las, R. (2012). Color y contenido de $\beta$-carotenos en boniatos, crudos y cocidos, durante su almacenamiento en Uruguay. Agrociencia, 16(1), 24-32.

Zeghad, N., Ahmed, E., Belkhiri, A., Vander Heyden, Y., \& Demeyer, K. (2019). Antioxidant activity of Vitis vinifera, Punica granatum, Citrus aurantium and Opuntiaficus indica fruits cultivated in Algeria. Heliyon, 5(4), e01575.

Zhang, K., Wu, Z., Tang, D., Lv, C., Luo, K., Zhao, Y., Liu, X., Huang, Y., \& Wang, J. (2016). Development and identification of SSR markers associated with starch properties and $\beta$-carotene content in the storage root of sweet potato (Ipomoea batatas L.). Frontiers of Plant Science, 7, 223. http://dx.doi.org/10.3389/fpls.2016.00223. PMid:26973669. 